\title{
Development and Ultrastructure of Cystoisospora canis Nemeséri, 1959 (syn. Isospora canis) Monozoic Cysts in Two Noncanine Cell Lines
}

\author{
Author(s): Sheila M. Mitchell , Anne M. Zajac , and David S. Lindsay \\ Source: Journal of Parasitology, 95(4):793-798. 2009. \\ Published By: American Society of Parasitologists \\ DOI: http://dx.doi.org/10.1645/GE-1951.1 \\ URL: http://www.bioone.org/doi/full/10.1645/GE-1951.1
}

BioOne (www.bioone.org) is a nonprofit, online aggregation of core research in the biological, ecological, and environmental sciences. BioOne provides a sustainable online platform for over 170 journals and books published by nonprofit societies, associations, museums, institutions, and presses.

Your use of this PDF, the BioOne Web site, and all posted and associated content indicates your acceptance of BioOne's Terms of Use, available at www.bioone.org/page/terms_of_use.

Usage of BioOne content is strictly limited to personal, educational, and non-commercial use. Commercial inquiries or rights and permissions requests should be directed to the individual publisher as copyright holder. 


\title{
DEVELOPMENT AND ULTRASTRUCTURE OF CYSTOISOSPORA CANIS NEMESÉRI, 1959 (SYN. ISOSPORA CANIS) MONOZOIC CYSTS IN TWO NONCANINE CELL LINES
}

\author{
Sheila M. Mitchell, Anne M. Zajac, and David S. Lindsay \\ Department of Biomedical Sciences and Pathobiology, Virginia Tech, 1410 Prices Fork Road, Blacksburg, Virginia 24061. e-mail: lindsayd@vt.edu
}

\begin{abstract}
Cystoisospora canis is a coccidial parasite of the intestinal tract that can cause severe disease in dogs. Clinical signs include watery diarrhea, vomiting, fever, and weight loss. Extraintestinal stages of Cystoisospora spp. have been demonstrated in the mesenteric lymph nodes of paratenic hosts. Information on the biology of extraintestinal stages of canine Cystoisospora species is limited. The current study examined the development of $C$. canis in 2 noncanine cell lines and the ultrastructure of the monozoic cysts that formed. Monolayers of bovine turbinate cells and African green monkey kidney cells were grown on coverslips and inoculated with excysted $C$. canis sporozoites. Coverslips were collected on various days and fixed and stained for light microscopy (LM) or transmission electron microscopy (TEM). A single, centrally located, slightly crescent-shaped sporozoite surrounded by a thick cyst wall within a parasitophorous vacuole was observed with the use of LM and TEM. No division and no multinucleated stages were observed with either LM or TEM. With TEM, typical organelles of sporozoites were observed, such as rhoptries, dense granules, a crystalloid body, polysaccharide granules, and a conoid. The structure and ultrastructure of $C$. canis monozoic cysts produced in vitro are similar to extraintestinal cysts of other Cystoisospora species in experimentally infected animals and those of Cystoisospora belli observed in immunocompromised humans. This is the first study that fully demonstrates in vitro the development of what structurally resemble extraintestinal cysts of a Cystoisospora spp.
\end{abstract}

Cystoisospora canis Nemeséri, 1959 (syn. Isospora canis), Cystoisospora ohioensis Dubey 1975, Cystoisospora burrowsi Trayser and Todd, 1978, and Cystoisospora neorivolta Dubey and Mahrt, 1978 are 4 coccidial parasites of dogs. Cystoisospora ohioensis, C. burrowsi, and C. neorivolta oocysts are structurally similar, usually grouped together, and termed $C$. ohioensis-like until further diagnosis can be made. Oocysts of $C$. canis are much larger than the oocysts of $C$. ohioensis-like coccidians and are easily identified in fecal samples (Lindsay et al., 1997). In the United States, canine coccidial prevalences range between 0.6 and $72 \%$ (Catcott, 1979).

Life cycle and transmission studies for $C$. canis in vivo are extensive (Nemeséri, 1960; Lepp and Todd, 1974; Dubey, 1975, Lepp and Todd, 1976; Hilali et al., 1979; Becker et al., 1981; Dubey, 1982; Mitchell et al., 2007). Recently, C. canis has been shown to be a primary cause of severe diarrhea in 8 -wk-old female beagle pups (Mitchell et al., 2007). Transmission is usually fecal-oral; however, ingestion of a paratenic host containing extraintestinal monozoic cysts will also cause a patent infection. Cystoisospora spp. can form monozoite cysts in extraintestinal tissues in both the canine definitive, and paratenic, hosts. Tissues most commonly infected with monozoic cysts are the mesenteric lymph nodes, spleen, and liver. Patent infections occur when a canine definitive host ingests paratenic hosts, such as a small rodent infected with these extraintestinal cyst stages (Dubey and Melhorn, 1978). However, the prepatent period of cyst-induced infections is shorter and clinical signs associated with cystoisosporosis are not as severe when compared to ingestion of sporulated oocysts (Dubey, 1975).

Few studies have examined the development of $C$. canis in cell culture (Fayer and Mahrt, 1972). The greatest development of coccidial parasites in vitro usually occurs in primary cell lines from the host (Doran, 1982). The current study examined the development of $C$. canis in African green monkey kidney cells and bovine turbinate cells. This study describes the light and electron microscopic structure of monozoic cysts that developed in these mammalian cell cultures.

Received 12 November 2008; revised 18 December 2008; accepted 16 January 2009.

* To whom correspondence should be addressed.

DOI: 10.1645/GE-1951.1

\section{MATERIALS AND METHODS}

\section{Inoculum}

Cystoisospora canis oocysts were identified based on structure in the feces of 2 littermate pit bull puppies that were estimated to be 1-2 mo of age (Mitchell et al., 2007). Oocysts used in this study were collected from the feces of experimentally infected 8-wk-old beagles (Mitchell et al., 2007). Oocysts were collected and sporulated as previously described (Mitchell et al., 2007).

Sporulated C. canis oocysts were ruptured with the use of a tissue grinder and then treated with an excysting medium containing $1.5 \%$ taurocholic acid and $0.5 \%$ trypsin in Hank's balanced salt solution without calcium and magnesium (HBSS) at 37 C. Excysted sporozoites were washed with HBSS, then concentrated by centrifugation and resuspended in $2 \%$ fetal bovine serum in RPMI 1640 media supplemented with $100 \mathrm{U}$ penicillin/ml and $100 \mathrm{mg}$ streptomycin/ml (maintenance medium).

\section{Cell culture}

Bovine turbinate cells (BT, ATTC CRL-1390, American Type Culture Collection, Manassas, Virginia) and African green monkey (Cercopithecus aethiops) kidney cells (CV-1, ATTC CCL-70, American Type Culture Collection, Manassas, Virginia) were grown to confluence on 22- $\mathrm{mm}^{2}$ glass coverslips in 6-well cell culture plates in growth media that consisted of $10 \%$ fetal bovine serum in RPMI 1640 medium, supplemented with $100 \mathrm{U}$ penicillin/ $\mathrm{ml}$ and $100 \mathrm{mg}$ streptomycin/ml. Coverslips were incubated at $37 \mathrm{C}$ in a humidified incubator containing $5 \% \mathrm{CO}_{2}$ and $95 \%$ air.

Cell monolayers were inoculated with $1 \times 10^{5}$ excysted $C$. canis sporozoites. At $24 \mathrm{hr}$ postinoculation (PI), the medium was removed, the monolayer was rinsed with HBSS, and the growth media replaced with maintenance media. Coverslips were removed and fixed in $10 \%$ buffered formalin on days 2, 6, 8, 10,13, and 15 PI for BT cells and days 2, 7, 10, 13, 16, and 17 PI for CV-1 cells. For light microscopic examination, the coverslip was removed from the $10 \%$ formalin and placed in $100 \%$ methanol for at least $1 \mathrm{~min}$. Coverslips were then stained with Diff-Quik ${ }^{\circledR}$ (Dade Berhing Inc., Newark, Delaware) and mounted on slides using Permount $^{\mathrm{TM}}$ (Fisher Scientific Company, Fair Lawn, New Jersey). The lengths and widths of 30 sporozoites and cyst walls and/or parasitophorous vacuoles were determined with the use of a calibrated ocular micrometer under oil immersion on days $2,10,15$, or 16 PI for BT and CV-1 cells, respectively. Cyst wall measurements were taken from the pellicle of the sporozoite to the tip of the cyst wall material. When no cyst wall was present, the parasitophorous vacuole (PV) was measured from the surface of the sporozoite zoite to the PV.

\section{Transmission electron microscopy}

African green monkey kidney cells were grown to confluence in $25-\mathrm{cm}^{2}$ tissue culture flasks and infected with $1 \times 10^{3}$ excysted $C$. canis sporozoites. On days 2, 6, 9, 11, and 15 PI, monolayers were removed 

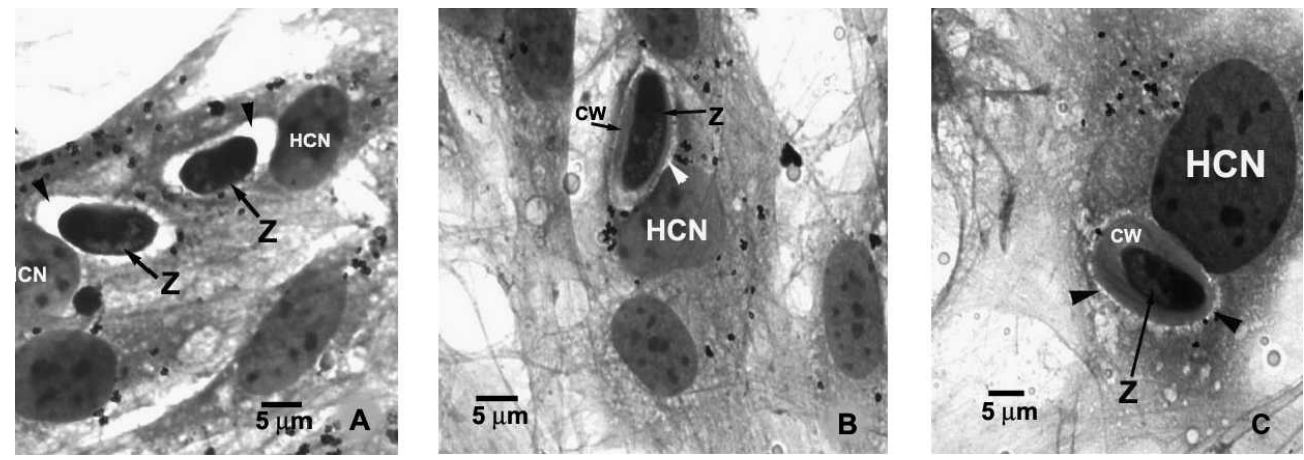

Figure 1. Cysts of Cystoisospora canis in bovine turbinate cells. Notice all cysts are located close to the host cell nucleus (HCN). (A) Monozoic cysts observed at 2 days PI. Note that sporozoites (Z) are in a parasitophorous vacuole (arrowhead) with no visible cyst wall. (B) Monozoic cyst at 10 days PI demonstrating that a cyst wall (CW) has begun to fill in the parasitophorous vacuole (arrow head) around the sporozoite (Z). (C) Monozoic cyst at 15 days PI demonstrating that the parasitophorous vacuole (arrow head) around the sporozoite (Z) is almost completely filled with the cyst wall (CW).

by scraping with a cell scraper and suspensions were pelleted by centrifugation. Pellets were fixed in $3 \%(\mathrm{v} / \mathrm{v})$ glutaraldehyde in PBS (pH 7.4). Cell pellets were postfixed in $1 \%(\mathrm{w} / \mathrm{v})$ osmium tetroxide in $0.1 \mathrm{M}$ phosphate buffer, dehydrated in a series of ethanol, passed through 2 changes of propylene oxide, and embedded in Poly/Bed 812 resin (Polysciences Inc., Warrington, Pennsylvania). Thin sections were stained with uranyl acetate and lead citrate and examined with a Zeiss 10CA TEM operating at $60 \mathrm{kV}$. Digital images were captured with the use of an ATM camera system (Advanced Microscopy Techniques Corp., Danvers, Massachusetts).

\section{RESULTS}

\section{Light microscopy findings}

Excysted C. canis sporozoites were able to infect both cell types and form monozoic cysts (Figs. 1-3). In both cell types, monozoic cysts had a single centrally located sporozoite within a PV. A thick cyst wall surrounded each sporozoite by the final collection day (Fig. 1). The cyst wall often shrunk down from the PV membrane, leaving a clear space surrounding cyst wall with its enclosed sporozoite (Figs. 1-3). Most sporozoites were slightly crescent shaped or oblong. Multinucleated stages, sexual stages, and oocysts were not observed in either CV-1 or BT cells. Replication of sporozoites was not observed with in the cyst wall at any time. The surface of intracystic sporozoites appeared

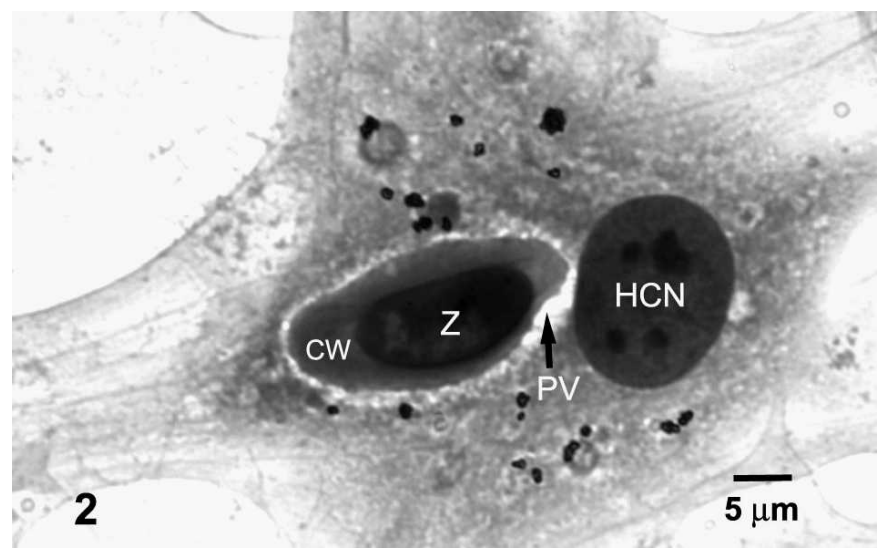

FIGURE 2. Light microscope appearance of a monozoic cyst in a bovine turbinate cell. A single sporozoite $(\mathrm{Z})$ is located in the center of the parasitophorous vacuole (PV) and surrounded by a thick cyst wall $(\mathrm{CW})$. Monozoic cysts were located close to the host cell nucleus (HCN). smooth, with no projections or visible grooves. An area of pale blue staining was observed toward the center and/or at the posterior end in the sporozoite cytoplasm (Fig. 1). In both cell types, sporozoites were positioned next to the host cell nucleus and in some cases were causing an indentation in the host cell nucleus. Two days PI, sporozoites in BT cells were in a PV with no visible cyst wall (Fig. 1A). In BT cells at 10 days PI, a cyst wall appeared to originate from the surface of the sporozoites and fill in the PV (Fig. 1B). By 15 days PI, the majority of the PV was filled with a thick cyst wall surrounding the sporozoite (Figs. 1C, 2). However, in CV-1 cells at day 2 PI, thick cyst walls had already begun developing in PVs surrounding some sporozoites. At day 10 PI, many sporozoites were still in a PV with little to no cyst wall material. By 16 days PI, many sporozoites were surrounded by thick cyst walls, although a few sporozoites remained in a PV with no wall present. Two sporozoites were observed in the same BT cell on day 15 PI (Fig. 3). This was not seen at any other time point in BT cells or in sporozoites grown in CV-1 cells. The

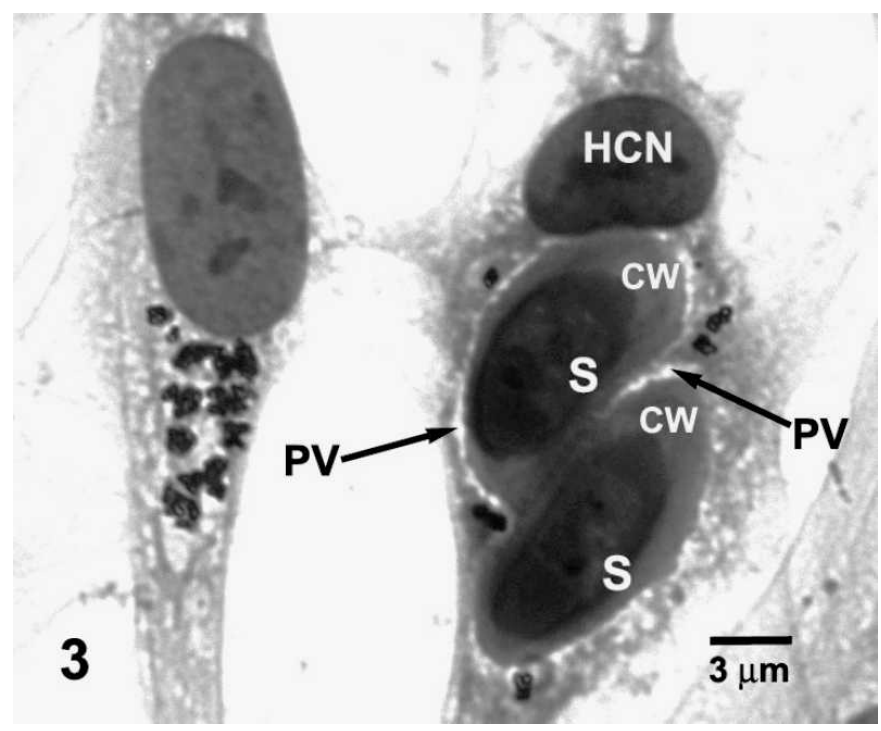

Figure 3. Two monozoic cysts of Cystoisospora canis developing in the same bovine turbinate cell at 15 days PI. Note that both sporozoites (S) appear to be in the same parasitophorous vacuole (PV) but the cyst wall (CW) around each sporozoite appears to have developed individually. Note that 1 cyst is near the host cell nucleus (HCN). 
TABLE I. Light microscopy measurements of 30 monozoic cysts grown in cell culture (mean \pm SD).*

\begin{tabular}{|c|c|c|c|c|}
\hline \multirow{2}{*}{$\begin{array}{c}\text { Day } \\
\text { postinoculation }\end{array}$} & \multicolumn{2}{|c|}{ Bovine turbinate cells } & \multicolumn{2}{|c|}{ African green monkey (Cercopithecus aethiops) kidney cells } \\
\hline & Sporozoite & $\begin{array}{l}\text { Parasitophorous vacuole (PV) and/or } \\
\text { cyst wall }\end{array}$ & Sporozoite & PV and/or cyst wall \\
\hline 10 & $\begin{array}{r}13.9 \pm 1.0 \times 5.8 \pm 0.6 \mu \mathrm{m} \\
(13.0-24.0 \times 7.5-12.0 \mu \mathrm{m})\end{array}$ & $3.4 \pm 1.1 \times 2.2 \pm 0.8 \mu \mathrm{m}$ & $\begin{array}{r}13.8 \pm 1.1 \times 6.2 \pm 0.6 \mu \mathrm{m} \\
(15.0-23.0 \times 6.0-11.0 \mu \mathrm{m})\end{array}$ & $3.1 \pm 1.3 \times 1.3 \pm 0.8 \mu \mathrm{m}$ \\
\hline 16 & NA & NA & $\begin{array}{r}13.8 \pm 1.0 \times 5.9 \pm 0.8 \mu \mathrm{m} \\
(16.0-24.0 \times 7.0-14.0 \mu \mathrm{m})\end{array}$ & $3.8 \pm 1.1 \times 2.4 \pm 1.0 \mu \mathrm{m}$ \\
\hline
\end{tabular}

* NA $=$ no measurements taken at this observation period.

measurements of 30 C. canis sporozoites and the surrounding cyst walls and/or PV grown in BT and CV-1 cells and collected on various days PI are presented in Table I.

\section{Ultrastructural findings}

Monozoic cysts were viewed in CV-1 cell samples collected for TEM (Figs. 4-7). Findings were similar to light microscopy in that only 1 sporozoite was seen in each cyst. Division of sporozoites within cysts was not seen at any time point. A cyst consisted of a single centrally located sporozoite surrounded by a thick granular/ fibrous cyst wall within a PV (Figs. 4-7). The cyst wall was next to the limiting membrane of the PV (Figs 4, 6, 7). Multiple infection of a single host cell was not observed with TEM. Some sporozoites had fibrillar material between their surfaces and the inner surface of the thick granular wall. It was noted that the particulate material of the cyst wall was not as thick in younger cysts. Tubular structures were

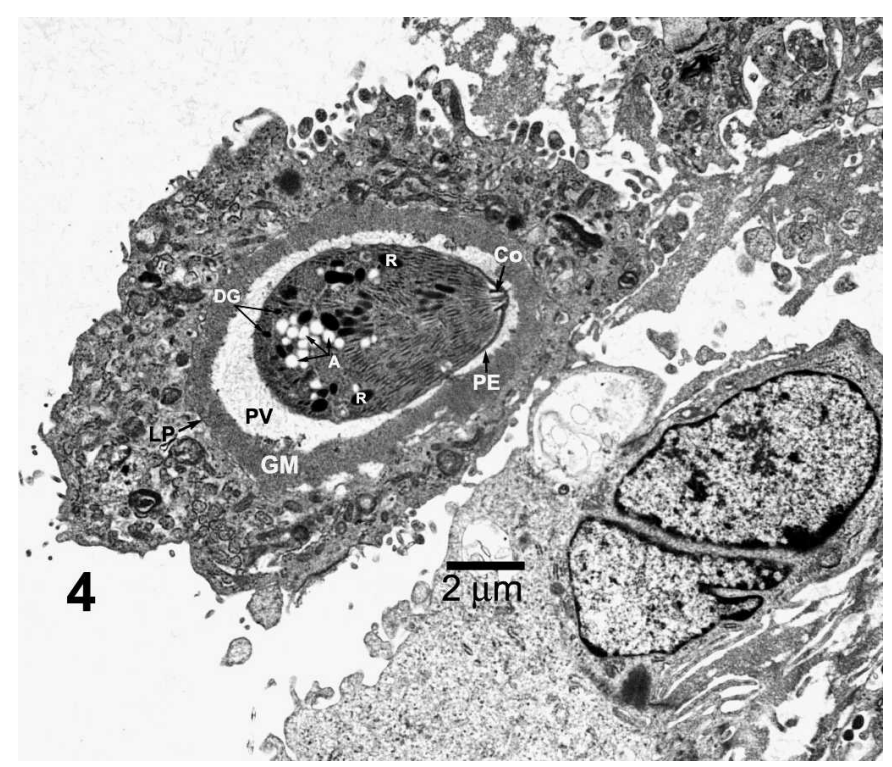

Figure 4. Transmission electron micrograph of a monozoic cyst of Cystoisospora canis in an African green monkey kidney cell at 15 days PI. Note the thick granular material (GM) that makes up the cyst wall, which is beneath the limiting membrane (LP) of the parasitophorous vacuole (PV). Note the sporozoite pellicle (PE) and typical sporozoite organelles consisting of amylopectin granules (A), rhoptries (R), dense granules (DG), and a conoid (Co). noted at the interface of the cyst wall and fibrillar material surrounding the sporozoite (Fig. 5). The fibrillar area appeared to originate from the surface of the sporozoite. A typical coccidian 3layered pellicle enclosed each sporozoite. The outer unit membrane surrounded the whole parasite and the inner membrane complex was interrupted at the anterior polar ring. Micropores were not seen. Organelles typical of coccidial sporozoites were present, such as a large crystalloid body, dense granules, and micronemes; granules similar to polysaccharides and lipids were located in the cytoplasm of each sporozoite (Figs. 4-7). The crystalloid body was composed of numerous, small, electron dense granules and was seen at the posterior end of the parasite (Fig. 7). The crystalloid body was circular in shape and was not bound by a membrane, but was surrounded by many dense bodies (Fig. 7). Amylopectinlike granules were seen anterior to the crystalloid body. The crystalloid body was in close proximity to the nucleus of sporozoites (not shown). At the apical end of the sporozoite, a conoid and polar rings typical of coccidian parasites was present (Figs. 4, 6). The ducts of at least 2 rhoptries were seen going through the center of the conoid. The number of rhoptries could not be determined. Micronemes were located through out the cytoplasm of sporozoites, but were more numerous in the anterior region of the sporozoite.

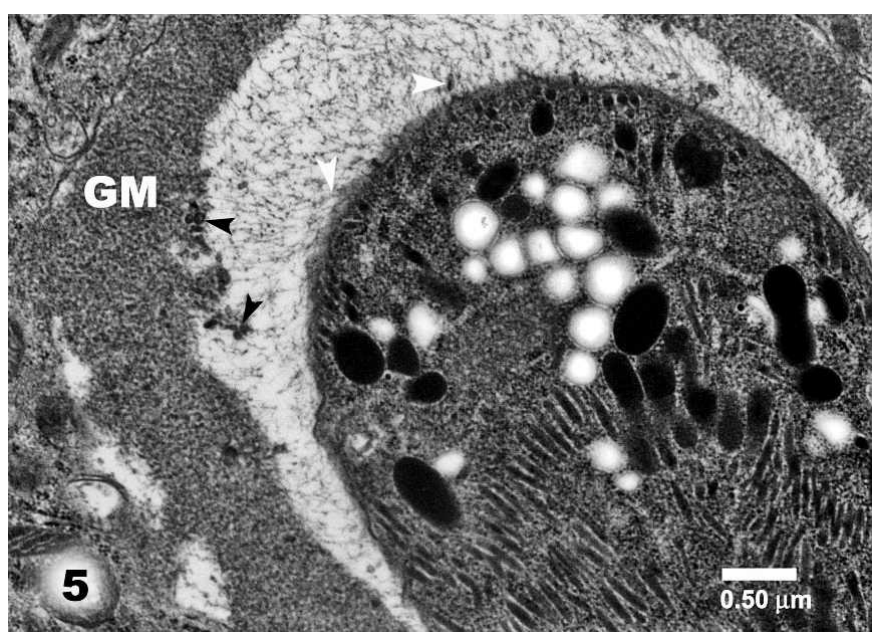

Figure 5. Transmission electron micrograph of a monozoic cyst of Cystoisospora canis in an African green monkey kidney cell 15 days PI. Observe the tubular structures (black arrowheads) at the interface of the granular material (GM) of the tissue cyst wall and fibrillar material (white arrowheads) surrounding the sporozoite. 


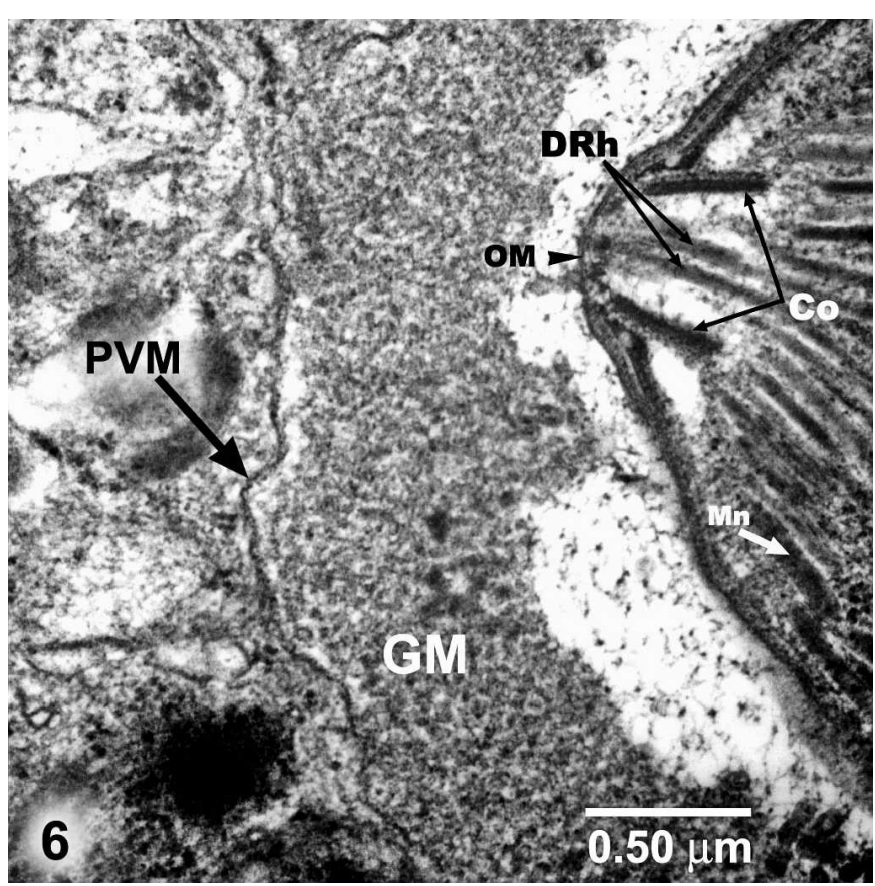

Figure 6. Transmission electron micrograph of the apical end of a Cystoisospora canis cyst at 15 days PI in an African green monkey kidney cell. The outer membrane unit (OM) of the 3-layered pellicle surrounds the whole sporozoite. Note the parasitophorous vacuole membrane (PVM) is in close association with the outer portion of the granular material (GM), which has filled in most of the parasitophorous vacuole. A typical coccidian conoid (Co) with 2 rhoptry ducts (DRh) running through the center is present. Micronemes $(\mathrm{Mn})$ can be seen throughout the sporozoite.

Dense bodies were located anterior and posterior to the sporozoites nucleus. Lipidlike and polysaccharidelike granules were present through out the cytoplasm of sporozoites and did not appear to be concentrated at any particular end of the sporozoite.

\section{DISCUSSION}

Cystoisospora species of dogs and cats are known to have extraintestinal stages (Dubey and Frenkel, 1972; Dubey, 1975, 1978; Dubey and Melhorn, 1978; Dubey, 1979). Most of the information known about these stages in canine and feline hosts comes from tissue feeding studies due to the rare observance of these stages in tissue sections or smears. These dormant stages are thought to be the cause of intermittent oocyst shedding through out the life of canine and feline definitive hosts. The present study shows that $C$. canis was able to enter 2 noncanine cell types and develop into monozoic cysts. These monozoic cysts grown in cell culture resemble extraintestinal cyst stages of other mammalian Cystoisospora species and contained a single sporozoite. This is the first study to fully describe monozoic cysts of any Cystoisospora species grown in cell culture and demonstrate that the stage present was a sporozoite.

Our study demonstrates that the organisms within these cyst stages were sporozoites, based on ultrastructure and the lack of division of organisms within the PV at any time point. No cystlike stages were reported in a TEM study of Cystoisospora suis developing in cell culture (Lindsay et al., 1991). Sporozoites penetrated cells and underwent division by endodyogeny (Lindsay et al., 1991). Malarial hypnozoites also originate from sporozoites

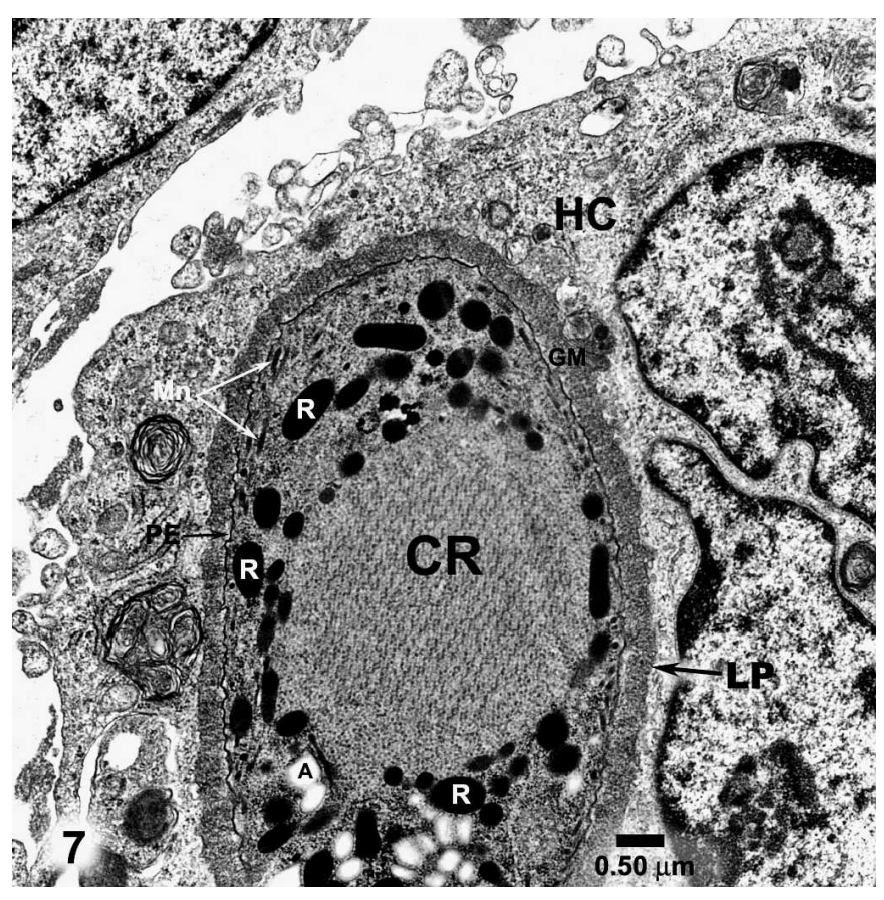

Figure 7. Transmission electron micrograph of a monozoic cyst of Cystoisospora canis in an African green monkey kidney cell collected 9 days PI. The cyst is in the host cell (HC) cytoplasm and located next to the host cell nucleus. Note the large posterior crystalloid body (CR), rhoptries (R), micronemes (MN), amylopectinlike granules (A), a 3-layered pellicle (PE), and a cyst wall of granular material (GM) within the limiting membrane (LP) of the parasitophorous vacuole.

and are the cause of relapse of malarial infections (Krotoski, 1989). Cystoisospora spp. merozoite formation in vitro usually occurs by endodyogeny (Fayer, 1972; Fayer and Mahrt, 1972; Fayer and Thompson, 1974; Fayer et al., 1984; Lindsay et al., 1991) and occasionally by schizogony (Fayer, 1972; Lindsay and Blagburn, 1987). Complete development of C. suis was observed in a porcine testicular cell line (Lindsay et al., 1998). Fayer and Mahrt (1972) observed reproduction, most likely by endodyogeny, of $C$. canis sporozoites grown in 5 different cell culture types, 2 of which were primary canine cell lines. The zoite pairs were attached at their posterior ends. In all 5 cell lines, sporozoites entered the host cells close to the nucleus and were surrounded by a PV (Fayer and Mahrt, 1972). They did not mention monozoic cystlike stages in any of the cell types they used. Sexual stages and oocysts of $C$. canis were not observed in either cell culture type.

Our light microscopy results found only 1 sporozoite present in each cyst grown in BT and CV-1 cells. This is in agreement with reports for human, feline, and other canine Cystoisospora species cysts with in host cells in vivo (Dubey and Melhorn, 1978; Dubey, 1979; Lindsay et al., 1997). In the present study, in a few instances with the use of light microscopy, it appeared that 2 sporozoites were able to enter a single BT host cell. Lindsay et al. (1997) reported that more than 1 monozoic cyst, lacking a developed cyst wall, was able to occupy the same host cell. Our study shows 2 sporozoites are able to develop to cysts within the same host cell. It is unclear whether the cysts share a PV or are in separate PV, but it does not appear that reproduction had taken place based on cyst wall formation around each sporozoite.

In our study, length and width of sporozoites within the monozoic cysts did not increase or decrease with time in cultured 
cells (Table I). The cyst wall around the single sporozoite grew larger with time to fill in the PV. Dubey and Melhorn (1978) measured single zoites within tissue cysts found in lymph nodes of mice fed $C$. ohioensis oocysts and found the zoites increased in size starting at 1 day PI with a mean measurement of $5.8 \times 2.1 \mu \mathrm{m}$ and ending at day 39 PI with a mean measurement of $12.8 \times$ $6.4 \mu \mathrm{m}$. At 14 day PI, the mean length and width of the zoites was $12.5 \times 6.2 \mu \mathrm{m}$, which was not different than the zoites measured on day 36 PI (Dubey and Mehlhorn, 1978). The ultrastructure of C. canis monozoic cysts grown in $\mathrm{CV}-1$ cells is similar to cysts found in tissues of paratenic hosts. The appearance of the centrally located sporozoite was typical of $C$. canis sporozoites (Roberts et al., 1970, 1972). The thick granular material that makes up the cyst wall has been observed in monozoic cyst stages of many Cystoisospora spp. (Dubey and Frenk1, 1972; Dubey and Melhorn, 1978; Melhorn and Markus, 1976; Boch et al., 1981; Lindsay et al., 1997). The granular material making up the cyst wall of $C$. canis and other Cystoisospora spp. is much denser than the fibrous covering of caryocysts containing in sporozoites of Caryospora bigenetica (Sundermann and Lindsay, 1989).

Crystalloid bodies have been described in sporozoites of most Cystoisospora spp. (Dubey and Frenkel, 1972; Mehlhorn and Markus, 1976; Dubey and Mehlhorn, 1978; Boch et al., 1981) and merozoites of C. suis (Lindsay et al., 1991) and have a similar appearance to beta-glycogen particles. Roberts et al. (1972) noted an anterior and posterior crystalloid body in freshly excysted $C$. canis sporozoites. They reported amylopectinlike granules along the periphery of the posterior crystalloid body, which is a typical association of refractile bodies in Eimeria species. Crystalloid bodies are thought to be analogous to refractile bodies found in sporozoites and merozoites of Eimeria species (Hammond et al., 1970; Roberts and Hammond, 1970). It has been proposed that they are associated with the transfer of stored nutrients, but their true function remains unknown (Garnham et al., 1969; Desser, 1970).

Cystoisospora belli (syn. Isospora belli) is a coccidial parasite of humans that can cause serious disease in immunocompromised hosts. Extraintestinal stages of $C$. belli have been observed in several patients with immunodeficiencies (Restrepo et al., 1987; Comin and Santucci, 1994; Michiels et al., 1994; Velásquez et al., 2001). In these patients, numerous monozoic cysts are present in extraintestinal tissue samples or in the lamina propria of the small intestine. Due to the large numbers of cysts, it is believed that these extraintestinal stages of $C$. belli represent merozoites that have left the intestinal tract (Lindsay et al., 1997). As previously mentioned, our cell-culture-derived cysts contained sporozoites. Because of their appearance and scarcity, it is probable that the parasites in cysts of canine and feline Cystoisospora spp. observed in vivo are sporozoites.

Siripanth et al. (2004) examined the development of $C$. belli sporozoites in human iliocecal adenocarcinoma (HCT-8), human larynx carcinoma (Hep-2), human fibroblast, bovine endothelial kidney (BEK), and African green monkey (Vero) cell culture cells. Sporozoites inoculated onto HCT-8 cells underwent schizogony and produced sexual stages, but no oocysts were observed in HCT-8 cells inoculated with sporozoites. Schizogony, but no sexual stages, was observed in Hep-2 cells. Siripanth et al. (2004) indicated that unizoic cysts were observed after inoculation of sporozoites onto BEK and Vero cells. It is not clear from their report if these were sporozoites that entered cells and did not develop or if they were true unizoic cysts. They did not do transmission electron microscopy on their samples. They did not mention a cyst wall surrounding these sporozoites (Siripanth et al., 2004) and their figure is not of high enough quality to determine if a cyst wall was present. Human fibroblasts were not susceptible to infection with $C$. belli sporozoites (Siripanth et al., 2004). Another study examined the development of $C$. belli sporozoites in HCT-8, epithelial carcinoma of the lung (A549), Maden-Darby bovine kidney (MDBK), and Vero cells (OliveiraSilva et al., 2006). They found that sporozoites entered all cell types and underwent development by endodyogeny by $24 \mathrm{hr}$. They did not observe sexual stages in any cell type (Oliveira-Silva et al., 2006). Most development occurred in Vero cells.

In our study, we did not use host- or site-specific canine cell types as in the studies mentioned above. This could explain the lack of reproduction in our study compared to other studies that observed division of sporozoites within the PV. Cystoisospora belli monozoic cysts in the spleen from a patient with AIDS averaged $12.2 \times 2.5 \mu \mathrm{m}$, and tissue cyst walls averaged $2.1 \mu \mathrm{m}$ (Lindsay et al., 1997). Average measurements of monozoic cysts from our study are similar to these measurements. Division of sporozoites or projections from the surface of sporozoites was not observed in any of the cysts in this study. Lindsay et al. (1997) noted grooves and projections in the pellicles of $C$. belli zoites, suggesting these projections could be mistaken for a second zoite within the same tissue cyst with the use of light microscopy. The surface of sporozoites of $C$. canis appears to be directly associated with the fibrillar material surrounding it. This was also observed in $C$. belli monozoic cysts found in mesenteric lymph nodes of an immunocompromised patient (Lindsay et al., 1997). However, the origin of the fibrillar material is currently unknown.

\section{ACKNOWLEDGMENTS}

This study was supported in part by grants from Bayer HealthCare Animal Health to D.S.L. and A.M.Z.

\section{LITERATURE CITED}

BeCKer, C., J. Heine, And J. Boch. 1981. Experimentelle Cystoisospora canis- und C. ohioensis-Infectionen beim Hund. Tierärtliche Umschau Zeitschrift für Gebiete der Veterinärmedizin 36: 1-8.

Boch, V. J., E. Göbel, J. Heine, And M. Erber. 1981. Isospora-Infection bei Hund und Katze. Berliner und Münchener Tierärztlliche Wochenschrift 94: 384-391.

Catcott, E. J. 1979. Canine medicine, 4th ed. American Veterinary Publications, Santa Barbara, California, 97 p.

Comin, C. E., And M. SAntucci. 1994. Submicroscopic profile of Isospora belli enteritis in a patient with acquired immune deficiency syndrome. Ultrastructural Pathology 18: 473-482.

Desser, S. S. 1970. The fine structure of Leucocytozoon simondi. III. The ookinete and mature sporozoite. Canadian Journal of Zoology 4: 641-645.

Doran, D. J. 1982. Behavior of coccidia in vitro. In The biology of the coccidian, P. L. Long (ed.). University Park Press, Baltimore, Maryland, p. 229-285.

Dubey, J. P. 1975. Experimental Isospora canis and Isospora felis infection in mice, cats, and dogs. Journal of Protozoology 22: 416-417.

- 1978. Life cycle of Isospora ohioensis in dogs. Parasitology 77: 1-11. . 1979. Life cycle of Isospora rivolta (Grassi 1879) in cats and mice. Journal of Protozoology 26: 433-443.

. 1982. Induced Toxoplasma gondii, Toxocara canis, and Isospora canis infections in coyotes. Journal of the American Veterinary Medical Association 181: 1268-1269.

- AND J. K. FRENKEL. 1972. Extra-intestinal stages of Isospora felis and I. rivolta (Protozoa; Eimeriidae) in cats. Journal of Protozoology 19: $89-92$. 
- AND H. Melhorn. 1978. Extraintestinal stages of Isospora ohioensis from dogs in mice. Journal of Parasitology 64: 689-695.

FAYER, R. 1972. Cultivation of feline Isospora rivolta in mammalian cells. Journal of Parasitology 58: 1207-1208.

- H. R. GAMble, AND J. V. ERnST. 1984. Isospora suis: Development in cultured cells with some cytological observations. Proceedings of the Helminthological Society of Washington 51: 154-159.

- AND J. L. MAHRT. 1972. Development of Isospora canis (Protozoa; Sporozoa) in cell culture. Zeitschrift für Parasitenkunde 38: $313-318$.

- and D. E. Thompson. 1974. Isospora felis: Development in cultured cells with some cytological observations. Journal of Parasitology 60: 160-168.

Garnham, P. C., R. G. Bird, J. R. Baker, S. S. Desser, and H. M. S. ElNAHL. 1969. Electron microscope studies on the motile stages of malaria parasites. VI. The ookinete of Plasmodium berghei yoelii and its transformation into early oocysts. Transactions of the Royal Society of Tropical Medicine and Hygiene 63: 187-194.

Hilali, M., F. A. Ghaffar, and E. Scholtyseck. 1979. Ultrastructural study of the endogenous stages of Isospora canis (Nemeseri, 1959) in the small intestine of dogs. Acta Veterinaria Academy Science Hungary 27: 233-243.

Hammond, D. M., C. A. Speer, and W. Roberts. 1970. Occurrence of refractile bodies in merozoites of Eimeria species. Journal of Parasitology 58: 189-191.

Krotoski, W. A. 1989. The hypnozoite and malarial relapse. Progress in Clinical Parasitology 1: 1-19.

Lepp, D. L., AND K. S. Todd, JR. 1974. Life cycle of Isospora canis Nemeseri, 1959 in the dog. Journal of Protozoology 21: 199-206.

, AND . 1976. Sporogony of the oocysts of Isospora canis. Transactions of the American Microscopical Society 95: 98-103.

Lindsay, D. S., AND B. L. Blagburn. 1987. Development of Isospora suis from pigs in primary porcine and bovine cell cultures. Veterinary Parasitology 24: 301-304.

- J. P. Dubey, And B. L. Blagburn. 1997. Biology of Isospora spp. from humans, nonhuman primates, and domestic animals. Clinical Microbiology Reviews 10: 19-34.

- AND M. A. Toivio-Kinnucan. 1991. Ultrastructure of developing Isospora suis in cultured cells. American Journal of Veterinary Research 52: 471-473.

, - M. A. Toivio-Kinnuncan, J. F. Michiels, and B. L. Blagburn. 1997. Examination of extraintestinal tissue cysts of Isospora belli. Journal of Parasitology 83: 620-625.
- D. P. Quick, A. M. Steger, M. A. Toivio-Kinnucan, and B. L. Blagburn. 1998. Complete development of the porcine coccidium Isospora suis Biester, 1934 in cell cultures. Journal of Parasitology 84: 635-637.

Melhorn, H., AND M. B. Markus. 1976. Electron microscopy of stages of Isospora felis of the cat in the mesenteric lymph nodes of the mouse. Zeitschrift für Parasitenkunde 51: 25-29.

Michiels, J. F., P. Hofman, E. Bernard, M.C. St. Paul, C. Boissy, V. Mondain, Y. Le Fichoux, and R. Loubiere. 1994. Intestinal and extraintestinal Isospora belli infection in an AIDS patient. Pathology Research Practice 190: 1089-1093.

Mitchell, S. M., A. M. Zajac, S. Charles, R. B Duncan, and D. S. LindSAY. 2007. Cystoisospora canis Nemeséri, 1959 (syn Isospora canis), infections in dogs: Clinical signs, pathogenesis, and reproducible clinical disease in beagle dogs fed oocysts. Journal of Parasitology 93: 345-352.

Nemeséri, L. 1960. Beitrage zur Aetiologie der Coccidiose der Hund. I. Isospora canis n. sp. Acta Veterinaria Academy Science Hungary 10: 95-99.

Oliveira-Silva, M. B., E. Lages-Silva, D. V. Resende, A. Prata, L. E. Ramirez, and J. K. Frenkel. Cystoisospora belli: In vitro multiplication in mammalian cells. Experimental Parasitology 114: 189-192.

Restrepo, C., A. M. Macher, and E. H. Radany. 1987. Disseminated extraintestinal isosporosiasis in a patient with acquired immune deficiency syndrome. American Journal of Clinical Pathology 87: $536-542$.

Roberts, W. L., AND D. M. Hammond. 1970. Ultrastructural and cytologic studies of the sporozoite of four Eimeria species. Journal of Protozoology 17: 76-86.

, J. L. Mahrt, And D. M. Hammond. 1972. The fine structure of Isospora canis. Zeitschrift für Parasitenkunde 40: 183-194.

Siripanth, C., B. Punpoowong, P. Amarapal, and N. Thima. 2004 Development of Isospora belli in Hct-8, Hep-2, human fibroblast, BEK and Vero culture cells. Southeast Asian Journal of Tropical Medicine and Public Health 35: 796-800.

Sundermann, C. A., AND D. S. Lindsay. 1989. Ultrastructure of in vivoproduced caryocysts containing the coccidian Caryospora bigenetica (Apicomplexa: Eimeriidae). Journal of Protozoology 36: 81-86.

Velásquez, J. N., S. Carnevale, M. Mariano, L. H. Kuo, A. Caballero, A. Chertcoff, C. IbáÑez, and J. P. Bozzini. 2001. Isosporosis and unizoite tissue cysts in patients with acquired immunodeficiency syndrome. Human Pathology 32: 500-505. 